\title{
The Beginnings of Christian Universal History From Tatian to Julius Africanus
}

\author{
Martin Wallraff \\ Theologische Fakultät, Universität Basel, Nadelberg 10, CH-4051 Basel, \\ Email: Martin.Wallraff@unibas.ch
}

When one speaks of Christian historiography in antiquity, the first thing that usually comes to mind is "Church history" in general and Eusebius' great achievement in this field in particular. Eusebius is called "the father of Church history", and quite rightly so ${ }^{1}$. However, one tends to forget the fact that this new literary genre was not an immediate success story. Following a few successors in the fourth and fifth centuries ${ }^{2}$, Christians did not write Church histories any longer for almost a thousand years. During this millennium - the Middle Ages - Christian historiography found its main expression in a different genre that became very popular, both in the East and in the West: chronicles, in many cases world chronicles, i.e. works in which the whole history of the world, or rather of mankind is described. Christian chronography also originated in antiquity, and the honorary epithet "father of Christian chronography" has been given to Julius Africanus (third century), whose Chronographiae (or what survives of it) are now accessible in a new critical edition ${ }^{3}$. The present paper deals with this aspect of early Christian historical thought.

Even if it is correct to call Julius Africanus the father of Christian chronography, fatherhood is often problematic: mater semper certa, pater incertus est. So, it might be worthwhile to ask again in which sense Julius Africanus is a father - and what exactly the child is called. This is what

1 This epithet was used by F.C. Baur, Die Epochen der kirchlichen Geschichtsschreibung, Tübingen 1852, 9, but it was not invented by him. Even if Eusebius himself did not put it in this way, it reflects his claim to have inaugurated a totally new literary genre (Eus., h.e. I 1,3).

2 See G. Marasco (ed.), Greek and Roman Historiography in Late Antiquity. Fourth to Sixth Century A.D., Leiden 2003, esp. the overview by H. Leppin, The Church Historians (I): Socrates, Sozomenus, and Theodoretus, 219-254.

3 The expression was used by $\mathrm{H}$. Gelzer, whose monograph still remains a milestone in the field (Sextus Julius Africanus und die byzantinische Chronographie, New York 1967 [= 1, Leipzig 1880; 2/1, Leipzig 1885; 2/2, Leipzig 1898], vol. 1,1). The edition is Iulius Africanus, Chronographiae. The Extant Fragments, ed. by M. Wallraff with U. Roberto and, for the Oriental Sources, K. Pinggéra, translated by W. Adler, GCS.NF 15, Berlin/ New York 2007. 
I want to do in the following pages: I will investigate the origins of what later became the Christian world chronicle.

Actually, the title of my paper does not speak of chronography, but of universal history, and the two are by no means identical, albeit similar to a certain extent. Chronography has the advantage of being a notion used in the antique sources themselves, whereas universal history is a category of modern scholars. It describes an approach to history, where the broadest possible horizon is applied, i.e. history from the remotest beginnings (wherever they are supposed to be) up to the present (and maybe even beyond). In this perspective the nature and "plan" of history as a whole come into sight, and hence of time in general. This is probably the reason why the concept of time-writing, xpovorpapia, occurs first and foremost in these contexts. The word is much older than "historiography" (which is a modern construct ${ }^{4}$ ), and it means a complete record of all times. The origins of the term are somewhat obscure, but it is interesting to note that the beginnings of its popularity roughly coincide with the rise of Christianity $^{5}$. This does not imply that it was a Christian invention, but apparently it served Christians' needs very well. For over one thousand years xpovorpapía along with the related term xpovikóv remained a leading paradigm in the perception of history. The Middle Ages in East and West wrote history in the form of chronicles, and these chronicles mostly had some universalist framework.

On the other side, the taste for universal history is not one of the constitutive elements of Christianity - quite on the contrary: whoever reads the primordial documents of Christianity, the New Testament and other contemporary writings, must get the impression that there was little or no interest in history in a Hellenistic sense, let alone universal history. Even Luke, who is known as the "historian" among early Christian writers, was interested only in the story of Jesus and the immediate sequel. The attempt to connect that story to general Roman history by occasional mentions of Augustus and Tiberius ${ }^{6}$ is little more than a feeble declaration of intent. This lack of interest in history among the earliest Christians is usually explained by the strong eschatological tension. Any inclination to reflect on time was outweighed by the expectation of the imminent end of time, and therefore it was more rewarding to write apocalypses than history.

4 In antiquity a term like "historiography" does not make sense, because iotopía alone (account, narration) is the equivalent of modern historiography (whereas history, understood

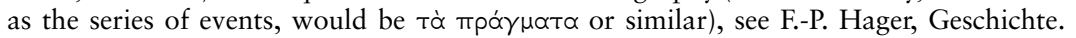
Historie I, HWP 3, Darmstadt 1974, 344f.

See note 45.

6 Luke 2,1; 3,1. On Luke as a historian see now J. Frey/C.K. Rothschild/J. Schröter (eds.), Die Apostelgeschichte im Kontext antiker und frühchristlicher Historiographie, BZNW 162, Tübingen 2009 (nondum vidi). 
This is certainly true, and it is also true that the receding of the concrete expectation that the world was near its end opened up the space for what I call the discovery of universal history in Christianity. This is the process I want to deal with in what follows, and I also hope to show that the link between this discovery and the whole issue of eschatology is much looser than usually surmised. In other words: the change in eschatology was a necessary, but not a sufficient condition for the process. Another issue I want to keep track of is the extent to which Christian apologetics influenced the discovery of universal history. I will come back to this point later.

At first sight it might seem that Christianity could not have encountered much trouble in discovering universal history, because it was already there. It was contained in the precious heritage which Christians had received from the Jewish tradition. In fact, the Hebrew bible in its final, canonical form already implies the idea of universal history ${ }^{7}$. Many single stories had become one history of the world, beginning with the creation and encompassing the political reality of Israel, with the lists of the fathers bridging the historical gaps. Christians just had to open their eyes to see what was there. However, it is well known that nothing is more difficult than to appreciate what you have inherited without thought or merit.

Even the desire to build a bridge from Biblical to Hellenistic history was already there; it can be perceived in the Septuagint translators and even more clearly in several later authors of whom unfortunately little is left ${ }^{8}$. When and in what way did Christian thinkers discover this heritage? What use did they make of it, transforming and enriching it in the process?

I will deal mainly with four authors, who actually wrote some sort of universal history (and I will, therefore, omit certain minor witnesses, where only certain elements of the genre occur). All four operate with concrete numbers and precise calculations for various parts of history. However, it must be said that in the case of all four, very little research has been done on these technical issues. This is particularly striking for Clement of Alexandria, who otherwise has attracted considerable scholarly attention in recent years ${ }^{9}$. Probably scholars refrain from these arguments,

7 The dating of the Old Testament canon has changed considerably during the last one or two generations of scholars. Normally it is now considered a product of the Hellenistic world, cf. C. Levin, The Old Testament. A Brief Introduction, Princeton 2005, 16-20. Levin rightly points out that only the Septuagint actually has a universal framework in a strict sense, in which it comprises also the future.

8 On the Septuagint see G. Larsson, The Chronology of the Pentateuch. A Comparison of the MT and LXX, JBL102, 1983, 401-409 and M. Rösel, Übersetzung als Vollendung der Auslegung. Studien zur Genesis-Septuaginta, BZAW 223, Berlin 1994, esp. 129-144, on the explanation of the chronology (which is quite different from the Hebrew version). On later Jewish authors see the brief overview in R.W. Burgess, Apologetic and Chronography. The Antecedents of Julius Africanus, in: M. Wallraff (ed.), Julius Africanus und die christliche Weltchronistik, TU 157, Berlin 2006, 17-42, esp. 25-28 and W. Adler's contribution in the present volume.

9 Many titles can be found in the bibliography of E. Osborn's excellent monograph (Clement of Alexandria, Cambridge 2005), where, however, chronology is not treated. Among 
because - in the words of Tertullian - the matter is "not so arduous as it would be tedious; it would require the anxious study of many books, and the fingers busy reckoning" ${ }^{10}$. This is still true, even in the age of electronic calculators, but the effort is worthwhile.

\section{Tatian the Syrian}

In the preface of his chronicle Eusebius states that "Moses flourished in the same time as Inachus", and to support this he gives a list of two Jewish and three Christian writers, who have each independently proved that fundamental assertion ${ }^{11}$. The Christians are Clement, Africanus and Tatian, and as in other cases, Eusebius willingly or unwillingly postulates a harmony that does not exist. As we will see, the three authors do not agree at all about the precise relationship between Moses and Inachus, and this is a crucial issue for Christian universal history. In any case, it is right that the earliest of these authors has the merit of having introduced the argument into Christian theology. Tatian wrote in the second half of the second century (although the precise dating is still somewhat

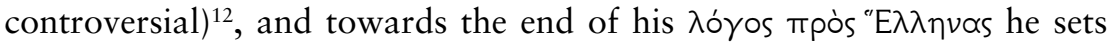
out "to demonstrate that our philosophy is older than the systems of the Greeks" ${ }^{13}$. This is, of course, the well-known argument for chronological precedence, the 'Altersbeweis', and the question ultimately comes down to "Homer or Moses?", to quote the title of a relevant monograph ${ }^{14}$.

This question is actually quite remarkable, because strictly speaking this is not a controversy about history but about literature. Tatian does not compare the creation myth in the bible with that in Plato's Timaios, nor does he investigate the date of Adam or Prometheus. Homer and Moses are of interest, because they are normative writers, and the implicit axiom is, of course, that the earlier of the two is closer to the truth. Tatian states that

the few recent studies of the relevant authors are C. Harrison, The Childhood of Man in Early Christian Writers (Theophilus, Irenaeus, Clement), Aug. 32, 1992, 61-76, and R. Mortley, The Idea of Universal History from Hellenistic Philosophy to Early Christian Historiography, TSR 67, Lewiston 1996.

10 Tert., apol. 19,5 (CSEL 69, 50,69-51,70 Hoppe): [...] nec arduum, sed interim longum. multis instrumentis cum digitorum supputariis gesticulis adsidendum est.

11 Eus., Chronicon, transmitted in Georgius Syncellus, Ecloga Chronographica (BSGRT,

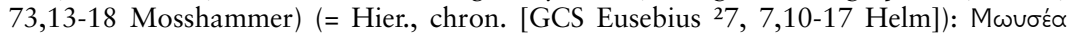

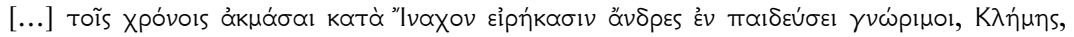
'A

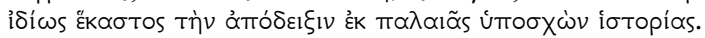

12 The most likely date is shortly after 176, see A.J. Droge, Homer or Moses? Early Christian Interpretations of the History of Culture, HUTh 26, Tübingen 1989, 83f. and 99f. (based on the dating proposed by R.M. Grant).

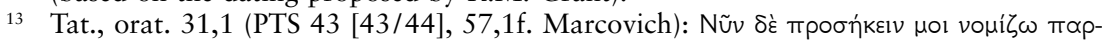

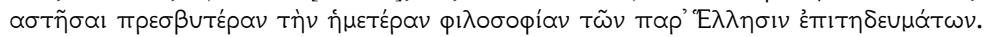

14 Droge, Homer or Moses (see note 12), here esp. 91-96. 
he wants to prove the superiority of his protagonist on the basis of pagan authors only, thereby "contending against you with your own weapons" 15 . The main burden of proof is on a quotation of Ptolemy of Mendes, according to which the biblical Exodus took place under a pharaoh called Amosis $^{16}$. This Amosis was a contemporary of Inachus, the legendary first king of Argus. As an additional witness, the Alexandrian writer Apion is quoted, certainly not a candidate for pro-Jewish forgeries ${ }^{17}$. This leads Tatian to the fundamental synchronism of Exodus and Inachos, which is required to determine the desired relationship between Homer and Moses. Since Agamemnon would be the $20^{\text {th }}$ king of Argus according to the lists of Castor of Rhodes ${ }^{18}$, there must be 20 generations between the Exodus and the Trojan War. The lifetime of Homer is unknown, but since he obviously cannot antedate the Trojan War, he must have lived at least about 400 years after Moses, quod erat demonstrandum ${ }^{19}$.

The simple equation between Exodus and Inachus is, of course, not universal history, but only a limited interest in one particular aspect of historiography. For the apologetic purpose of his book Tatian could stop here, but he goes on to show further fruits of his reading. He gives a long list of all those persons and events in Greek history that are to be assigned to the time-span between Inachus and the Trojan War, thus demonstrating that all this is post-Moses. At the end he claims to have given an account of all important issues, "of the times and their writing" - I translate literally to show how close we are to the xpovorpapia of later authors: $\pi \varepsilon p i$

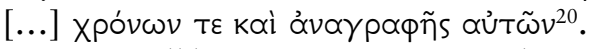

As is well known, Tatian is mainly interested in apologetics, and the tone is very polemic indeed, but this should by no means be seen as a contrast to a fundamentally scholarly approach. Apologetic is in the service of the search for truth, it is not opposed to $\mathrm{it}^{21}$. I will come back to this point later. It goes without saying that no eschatological interest whatsoever can be perceived in Tatian's diatribe. Once established, the synchronism of Moses and Inachus became widespread among Christian authors.

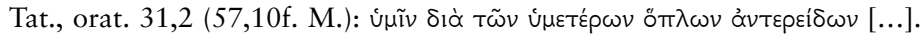

FGH 3C, 611, F1a, 119 Jacoby; cf. Tat., orat. 38,1.

FGH 3C, 616, F2a, 123 J.; cf. Tat., orat. 38,2.

8 Tat., orat. 39,1 (70,1-5 M.); Castor (FGH 2B, 250,F3, 1137-1139 Jacoby) is not actually quoted as the source of this list, and he may not be used directly, but ultimately the material derives from him.

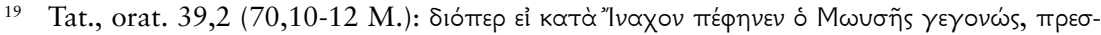

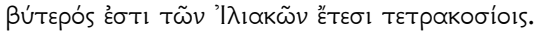

20 Tat., orat. 41,6 (74,21f. M.).

21 Droge, Homer or Moses (see note 12), 92 and 96, is right in calling Tatian's approach "scientific".
} 


\section{Theophilus of Antioch}

However, Theophilus, our next author, chose a different approach, apparently unaware of his predecessor's work, although the literary framework is similar. At the end of his apologetic work Ad Autolycum Theophilus embarks on a chronological account of universal history $(\theta \dot{\varepsilon} \lambda \omega[\ldots]$ Tà

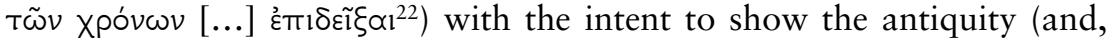
thus, superiority) of the Jewish-Christian tradition. This account is not limited to one central axis of events before or after which all events can be placed. And it is not limited either to the dating of prominent authors, but rather it encompasses for the first time history as such and history as a whole. Theophilus has a great advantage compared with all Hellenistic writers when it comes to the beginnings of history. The biblical tradition allows him to start at the absolute beginning of events, time zero, as it were, the beginning of history in the modern sense of the word, not just beginning of iotopía as the record of events, which starts with the origins of human memory and writing. In Theophilus we find for the first time an attempt at dating everything with precision in terms of years of the world from its creation. He wants to give "the whole number of events and times" 23 . Therefore, his account goes well beyond ancient times (which would be sufficient for purposes of apologetic); it extends as far as the author's own times, i.e. up to the death of Marcus Aurelius in the year 180 , which is therefore a terminus post quem and probably quite near to the date of writing ${ }^{24}$.

The main chronological problem for Theophilus, as for all other antique chronographers, is the way in which Jewish and Greek history have to be coordinated. Theophilus knows of three points of contact between the two strings, the first and second of which remain, however, rather vague. There are actually good reasons to remain vague in the first case, where the Flood of Noah is equated to that of Deucalion ${ }^{25}$. For if the consequences were drawn, Greek history would start incredibly early, more than 2500 years before the Persians (Deucalion usually is supposed to come after the mythical forefather Ogygus), which would not only run counter to the apologetic aim, but would also be inconceivable in the terms of Hellenistic

22 Thphl. Ant., Autol. III 16,1 (PTS 44 [43/44], 116,1f. Marcovich). The chronological treatise extends from there to the end of the whole work (III 30,4). See Droge, Homer or Moses (see note 12), 102-123; W. Kinzig, Novitas Christiana. Die Idee des Fortschritts in der Alten Kirche bis Eusebius, FKDG 58, Göttingen 1994, 378-383; Burgess, Apologetic (see note 8), 33f. A useful table of Theophilus' chronology can be found in R.M. Grant, Introduction, in: Theophilus of Antioch. Ad Autolycum. Text and Translation by R.M. Grant, OECT, Oxford 1970, (ix-xxv) xxiii-xxv.

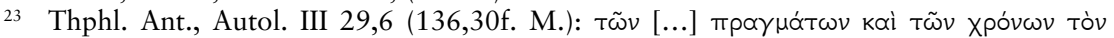

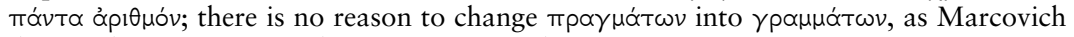
does without support in the manuscript tradition.

24 Thphl. Ant., Autol. III 28,6 (134,8-10 M.).

25 Thphl. Ant., Autol. III 18,5 (118,11-16 M.). 
historiography. The second point of contact is the famous dating of Moses. Here again Theophilus is somewhat blurry: "Moses and his followers are proved to be 900 or even 1000 years prior to the Trojan War" ${ }^{26}$. This time, on the contrary, almost no time would be left for Greek history between the Trojan War and the Persian kingdom. The Persians provide the only reliable synchronism, which actually is the basis of Theophilus' chronology, and this is the fact that the return of the Jews to Jerusalem after the Babylonian captivity occurred at the beginning of the Persian kingdom ${ }^{27}$. Here again, there are some strange inconsistencies in the details, but on the whole this synchronism makes sense and is accepted in historiography up to this day.

The number of years from the creation to the death of Marcus Aurelius is given as $5695^{28}$. Is it mere chance that this number would fit well into an overall framework of a period of 6000 years for the whole of history? As is well known, the Jewish-Christian tradition often assumed (and in America nowadays sometimes still assumes) such a framework, based on the six days of creation and the psalm verse, according to which each day of the Lord equals 1000 years $^{29}$. Theophilus may have known this scheme (the first references being in the epistle of Barnabas and in Irenaeus ${ }^{30}$ ), and it may also have indirectly influenced his calculations because he certainly drew on earlier sources, although we do not know on which. The whole question is quite important, because the 6000-year-scheme would imply that Theophilus' chronology indirectly allows us to calculate the precise date of the end of the world. Ultimately, it comes down to the question: "Théophile d'Antioche est-il millénariste?" - which is the title of a recent article on the issue ${ }^{31}$. Older literature often attributed a millenialist approach to Theophilus, but Zeegers is in my opinion right in saying: "Il serait vain de vouloir y lire autre chose que ce que l'auteur y a inscrit" 32 . The text is preserved in its entirety, and the author had every opportunity to communicate whatever he considered important. It is futile to surmise hidden messages that are not there. Even if Theophilus knew of the 6000-year-scheme, a fortiori it can be said that he was simply not interested in it, or, for that matter, in any form of eschatological horizon of his chronology.

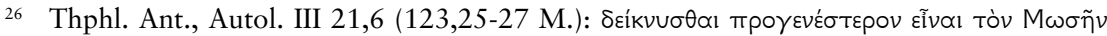

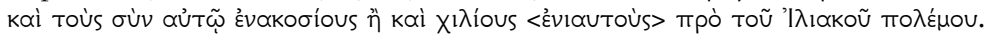

27 Thphl. Ant., Autol. III 25,4f. (130,24-36 M.)

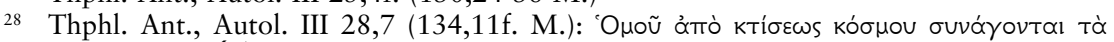

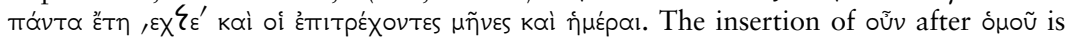
unnecessary.

29 Ps 90,4. On the origins of this scheme see O. Böcher, Chiliasmus. I. Judentum und Neues Testament, TRE 7, Berlin 1981, 723-729, esp. 725f.

30 Barn. 15,4 and Iren., haer. V 28,3; $23,2$.

31 N. Zeegers, Théophile d'Antioche est-il millénariste?, RHE 91, 1996, 745-784.

32 Zeegers, Théophile d'Antioche (see note 31), 755. 
Basically the same must be said on the other famous silence in Theophilus, and that is the total absence of $\mathrm{Christ}^{33}$. On the basis of the numbers he provides, it is possible to calculate with a reasonable degree of certainty the year of the incarnation. It probably would have to be put in the year $5514^{34}$. There is absolutely no reason to think that this year had particular weight in his system, and even less reason to think that he favoured a round number like 5500. Christology is simply not needed to calculate "the whole number of events and times" in universal history. A few years later, Clement of Alexandria was to introduce the question into Christian chronography, but as we will see, quite en passant and without strong emphasis for his chronological system.

\section{Clement of Alexandria}

Clement certainly was a learned man and an extraordinary scholar. As with the two previous authors, his work encompassed both the apologetic and the scholarly, but his emphasis has now shifted to the latter. Towards the end of the first book of his stromateis he gives a lengthy treatise on chronology which by far exceeds that of his predecessors both in length and wealth of information ${ }^{35}$. Clement had certainly done an awful lot of reading for this work; reading always had been his strong side, sometimes at the expense of critical reflection and selection of what he had read. The consequence is that one can easily draw up an impressive list of various sources, both of known and anonymous authors, used by Clement at first or second hand ${ }^{36}$, but it is virtually impossible to determine what comes from where and especially what is ultimately Clement's own opinion. The chapter on chronography is a nightmare for source criticism, and although a number of relevant studies appeared about 100 years ago during the heyday of source criticism in German classical philology, no satisfactory and generally accepted results have been established ${ }^{37}$.

33 This has always confused later readers. For a recent attempt at explaining the fact see J.P. Martín, La saggezza creatrice secondo Teofilo d'Antiochia ed i suoi silenzi cristologici, Aug. 32, 1992, 223-235.

34 Cf. Zeegers, Théophile d'Antioche (see note 31), 750-752.

35 Clem., strom. I 21,101-147. The text requires 28 pages in the GCS edition (GCS Clemens Alexandrinus ${ }^{4} 2,64,18-92,3$ Stählin/Früchtel). Apart from the older literature given below (see note 37) see Droge, Homer or Moses (see note 12), 124-152; Mortley, The Idea (see note 9), 127-147 and Burgess, Apologetic (see note 8), 34f.

36 An impressive overview is given by Stählin's index of quotations (Zitatenregister, in: Clemens Alexandrinus, 4. Band, Register, Erster Teil. Zitatenregister, Testimonienregister, Initienregister für die Fragmente, Eigennamenregister, hg. von O. Stählin, 2., bearbeitete Auflage hg. von U. Treu, Berlin $\left.{ }^{2} 1980,1-59\right)$. Cf. furthermore on Clement's method A. van den Hoek, Techniques of Quotation in Clement of Alexandria. A View of Ancient Literary Working Methods, VigChr 50, 1996, 223-243.

37 Within little more than a decade were published A. Schlatter, Der Chronograph aus dem zehnten Jahre Antonins, TU 12,1, Leipzig 1894; W. Christ, Philologische Studien 
At least two large chronological systems seem to have been combined to form the chapter on chronology, or rather to have been juxtaposed. In many cases Clement gives the number provided by an anonymous source

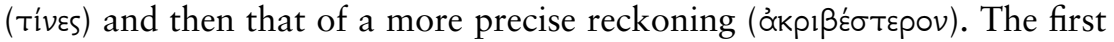
source probably concluded with the $10^{\text {th }}$ year of Antoninus Pius, i.e. AD 148. The second goes on to the death of Commodus in 192, and that means right up to Clement's own time ${ }^{38}$. In both cases the theoretical claim would be to calculate universal history from the creation to the present mainly on the basis of the numbers provided by the Hebrew tradition, but at least in the form given by Clement the sums are less important than the details. He also gives a list of the Roman emperors, interestingly "in order to determine the birth of the Savior" 39 , and in fact he speaks at some length on the issue. But the date in terms of anni mundi does not seem to be terribly important; he does not even bother to calculate the precise number, although it can be easily done on the basis of the material provided by him. Christ would be born in the year of the world $5590^{40}$, and although the event itself is considered important theologically, no chronological weight is given to the date.

Just in passing it should be noted that Clement is the first author to speculate about precise days of the basic events in the life of Jesus (birth, passion),

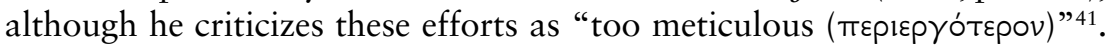
This is where we find the famous first mention of Epiphany on 6 January, as a feast of the baptism of Jesus ${ }^{42}$. This is essentially all we hear about the life of Jesus.

zu Clemens Alexandrinus, ABAW.PP 21, 1901, 455-528, esp. 494-526; J. Gabrielsson, Über die Quellen des Clemens Alexandrinus, 2 vols., Uppsala 1906-1909.

38 At the end of his treatise Clement calculates the sum from Moses to the present according to two (or three) systems (Clem., strom. I 21,147,3f. [91,17-19 S./F.]). One finishes in "the $10^{\text {th }}$ year of Antoninus", "others ( $\left.\alpha^{\prime} \lambda \lambda_{\circ \mathrm{ol}}\right)$ " go on until the death of Commodus. The first source has been analyzed by Schlatter, Der Chronograph (see note 37).

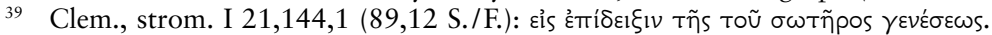

40 This number can be calculated on the basis of Clem., strom. I 21,144,3 (89,17-19 S./F.): 5784 years from Adam to the death of Commodus, and Clem., strom. I 21,145,5 (90,1318 S./F.): 194 years from the birth of Christ to the death of Commodus. However, on the basis of the numbers given in Clem., strom. I 21,140,2-6 (87,2-12 S./F.), a slightly different calculation can be drawn up: 5819 years from Adam to the death of Commodus, hence birth of Christ in AM 5625.

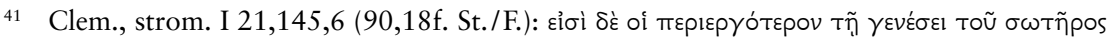

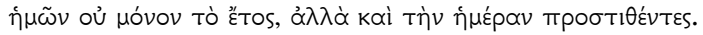

42 Clem., strom. I $21,146,2\left(90,22-24\right.$ S./F.). The text mentions the $15^{\text {th }}$ or the $11^{\text {th }}$ day of the month of Tybi (= January 10 or 6 ) as a feast among the Basilidians. This text has been widely discussed, the last contribution being that of F. Förster, Die Anfänge von Weihnachten und Epiphanias. Eine Anfrage an die Entstehungshypothesen, STAC 46, Tübingen 2007, 57-67. Förster rightly points out that the text has mostly been overestimated and that it cannot carry the weight it usually has to carry in the early history of the feast. However, the text does mean something, and Förster fails to come up with a convincing explanation of how it actually originated. 
For the scheme of the 6000 years the same consideration can be and should be made as in Theophilus: it may well be that Clement knew of that tradition, and his system(s) could fit easily into such a framework. However, there is no reason to think that he was interested in it, much less in its possible millenialist consequences. On the contrary, the larger context in the stromateis suggests differently. "The philosophy of the Hebrews will be demonstrated beyond all contradiction to be the most ancient of all wisdom," ${ }^{43}$ this is the programmatic beginning of the treatise. Previously he has spoken of the role of philosophy in general, and after the chronological excursus he draws the consequence and speaks of Plato as a pupil of Moses. Actually, his starting point is the old equation Moses-Inachus (taken over from Tatian) ${ }^{44}$, and the entire first part, more than two thirds of the whole text, deals with history post-Moses. The apologetic argument of old age is Clement's main concern, and no eschatological (or protological) horizon is needed to make this point.

Clement calls his own undertaking several times a xpovorpapía, and it is his merit to have introduced the word as a technical term into the debate ${ }^{45}$. The concept of time-writing, or rather writing of time, expressed well what it was all about. The next author I am going to speak about uses the word as a title for an impressive work in five books. I am talking, of course, of Julius Africanus and his xpovoypapíal. Before I turn to him, one last observation on Clement. Already for Theophilus an important argument in favour of the truth of the Hebrew tradition was that the predictions of the prophets had turned out to be true. The most intriguing and complicated of all prophets in this respect was Daniel: obscure enough to permit various interpretations, concrete enough to permit solid calculations. Clement was the first to introduce his evidence into Christian universal history, and this was to become a standard topic for all subsequent writers, although Clement's specific interpretation was not normally shared. For him the famous 490 years start with the beginning of the exile - earlier than in most later authors -, and they reach up to the destruction of the temple - later than in most later authors ${ }^{46}$. Of

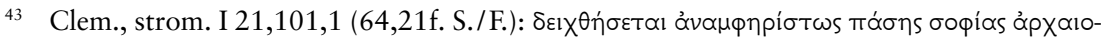

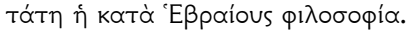

44 Clem., strom. I 21,101,3-5 (65,1-13 S./F.), presumably taken from Tat., orat. 38. However, Christ, Philologische Studien (see note 37), 497f.505, suggests that Tatian and Clement drew upon the same source (unknown to us, possibly Cassian), since Clement's material is somewhat richer.

45 Clem., strom. I 21,112,4; 114,1; 116,3; 121,4 (71,25-28; 72,13-17; 73,19-22; 76,16-22 S./F.) . The famous work of Eratosthenes of Cyrene may also have circulated under this title (FGH 2B, 241,F3, $1013 \mathrm{~J}$.; see also F1b, $1013 \mathrm{~J}$.), although this is by no means certain. His followers Apollodorus of Athens (FGH 2B, 244, 1022-1128 J.) and Castor of Rhodes (FGH 2B, 250, 1130-1145 J.) may have used the term Xpovikó.

46 Clem., strom. I 21,125f. (78,6-79,7 S./F.), cf. also I 21,140,7 (87,12-16 S./F.) (not consistent with what immediately precedes). Both Africanus and Eusebius refer the endpoint of this time-span to Christ. In order to reach this point, Africanus starts from the reconstruction of Jerusalem under Nehemiah (Cf. Afric., Chronographiae F93 [GCS. 
course, the life of Christ (the "anointed") also has a certain importance, but as we have seen only in a secondary way.

This is totally different a few years later in Hippolytus' commentary to Daniel. In a literary genre which has nothing to do with universal history, an important decision for chronology is made (or attested for the first time). Unlike in all sources quoted so far, the context and atmosphere of this work is characterized by a strong eschatological tension. Although Hippolytus tends to refrain from concrete calculations of the end of time, he finally indulges the curiosity and pressure of his readers and says what must not be spoken out: reckoning "the times from the creation of the universe and of Adam" has led him to the result that Jesus must be born in the year $5500^{47}$. A few lines later we find the scheme of the 6000 years of the world and the expectation of the great Sabbath, a millennium of peace. Therefore, the dating of Christ serves to appease certain fears of a very imminent end because in this system almost 300 years would still be left before the coming of the end.

The reason for the date of the incarnation given by Hippolytus is somewhat bizarre: The ark of Noah measured $2 \frac{1 / 2}{2}$ by $1 \frac{1 / 2}{2}$ by $1 \frac{1}{2}$ yards, he says; the sum of these three figures is $5 \frac{1}{2}$, and therefore Jesus must be born in $5500^{48}$. I am not sure whether pagan readers would have been very impressed by an argument of this sort. It certainly cannot be called scientific, if we understand this in terms of the scholarly tradition of Hellenistic historiography.

\section{Julius Africanus}

It is unclear whether Africanus knew Hippolytus' commentary on Daniel, but he certainly knew his date of the incarnation, because it became one of the key figures of his own chronological system. He also was aware of the importance of the book of Daniel; he may even have written an independent treatise on the interpretation of the seven hebdomads in Dan

NF 15, 280,54-282,62 Wallraff/Roberto], see also F78 [236 W./R.]), which, according to Eusebius, is somewhat too late (various attestations from the chronicle, see Afric., Chronographiae T78a [236 W./R.]). For the exegesis of the important Daniel pericope the monograph by F. Fraidl (Die Exegese der siebzig Wochen Daniels in der alten und mittleren Zeit, Graz 1883) is still very useful.

47 Hipp., Dan. IV 23,2f. (GCS.NF 7,244,6-12 Bonwetsch/Richard): oi rà xpóvol åmò

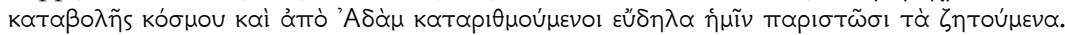

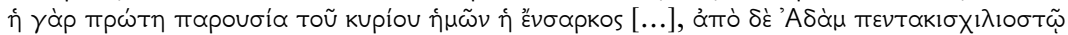

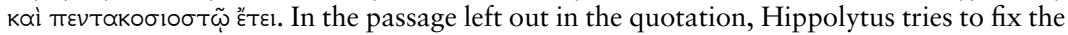
time even further by indicating the precise day of the incarnation (April 2). This passage is particularly problematic, as far as textual criticism is concerned. However, there is no need to go into the details here.

48 Hipp., Dan. IV 23,4-6. 
949. The treatise does not survive. What we have, are a few fragments of his xpovorpapial, originally a voluminous work consisting of five books, written in $221^{50}$. In these fragments nothing apart from the year 5500 reminds us of Hippolytus' exegesis of Daniel. In particular, there is not the slightest sign of eschatological tension. Only the precise and correct dating of the biography of Jesus was of fundamental importance for Africanus. In the preserved fragment on the Passion and Resurrection we see him in top form: astute, well-read, only a bit knotty at times. The "round" date of 5500 for the incarnation, which he did not "invent" or calculate independently but found in the tradition, complied with his sense for the symbolism of numbers, like the year 3000 for the death of Peleg, "in whose days the earth was divided" 51 .

Now it is difficult to decide whether Africanus was aware of the big "symbolic" year 6000, the end of the world. Given that it was "in the air" and given his sense for round numbers, it seems difficult to imagine that his chronological system did not imply this upper end of history. However, there is no trace of this in the extant material. How should we interpret this silence? Obviously the situation is different from Theophilus and Clement, because of the fragmentary state of preservation of the text. Anything could have been said and could be lost now. Some surviving texts would have given excellent opportunity to speak about these issues, and the author missed the chance ${ }^{52}$. But it is useless to speculate about what we do not have.

However, since there is no evidence in the preserved fragments, no evidence in the preceding history of Christian chronography, no evidence in Jewish or Hellenistic parallels, I would assume that Africanus was well aware of the eschatological implication of his system, but he was not particularly interested in it. He may or may not have spoken about it, but eschatological tension is not the hermeneutical key to his work and to his interest in universal history ${ }^{53}$. Actually, writing five books of complicated

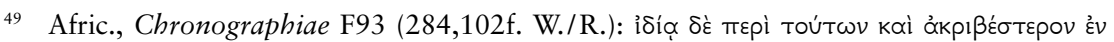

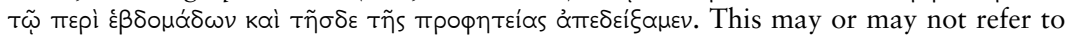
a separate work.

so On 221 as the probable date of writing see Wallraff, Iulius Africanus (see note 3), XVIIf.

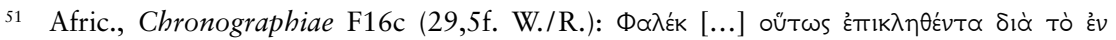

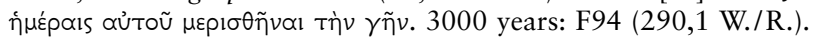

52 E.g. F15, F93 or F94 (24; 276-286; 290 W./R.). The last case is especially difficult. Ps. Eustathius of Antioch gives information apparently deriving from Africanus, and then continues to insert this information into a millenialist framework. Is this also taken from Africanus? We do not know. Therefore, this part of the text has been given in small print in the edition.

53 There is certainly no factual basis for bold statements like: "For Africanus ... the primary task of historical chronology was to elucidate the future, in advance", or "In his view, chronology should serve eschatology" (A. Grafton/M. Williams, Christianity and the Transformation of the Book. Origen, Eusebius and the Library of Caesarea, Cambridge MA 2006, 151f.). 
(and sometimes boring) calculations in order to placate a few nervous sectarians would be like using a sledgehammer to crack a nut.

So what was the driving force of the author to write his work? The Chronographiae is the first instance where Christian universal history appears in an autonomous work without an apologetic context. It is true that occasionally there are still traces of the apologetic heritage of the genre ${ }^{54}$, but in other cases Africanus leaves the well trodden path and resists the temptation to derive apologetic benefit from his chronological considerations. This is particularly apparent in the preface to his third book, where he deals with the classical problem of the dating of the Exodus. Although he mentions Ptolemy of Mendes and Apion and although he probably knew the tradition of equating Moses with Inachus, he opts for a different solution: the Exodus is paralleled with the flooding of Ogygus, and hence an event in Attic history ${ }^{55}$. This is later than the conventional date; it corresponds to the $55^{\text {th }}$ year of the reign of Inachus' son Phoroneus in the Argive kingdom. Unlike in Tatian and many others, Moses did not lead the Exodus at the time of Inachus, but he was born at that time. The consequence is, of course, similar: the Trojan War and all other events of real Greek history (as opposed to myth) took place after Moses. Africanus gives a short list of such events and persons ${ }^{56}$ - without any polemic tone, and without any hint to possible claims of truth. Moses does not appear as the law-giver, and Homer is not even mentioned. Everything is in the interest of establishing a firm chronology of Greek (and universal) history.

It is impressive to see how Africanus took great pains to draw up a complete chronological system of the history of mankind and to make it work (reasonably well). There is no need to expand on this, because the new edition should give a good impression of the whole system ${ }^{57}$. The decisive point is that Africanus was in search of knowledge for the sake

54 Polemics against the Marcionites: Afric., Chronographiae F93 (284,104-106 W./R.), against Egyptian or Chaldean chronology: F15 (24 W./R.). It should also be noted that possible apologetic passages in the work would have relatively good chances to survive in the filter of later transmission, because they would fit into the criteria of later Christian orthodoxy.

$55 \quad$ F34 (74,38-40 W./R.). Ptolemy and Apion: F34 (80,80-87 W./R.) (Africanus probably

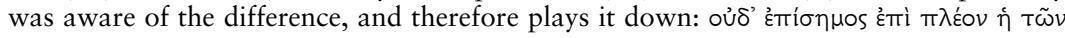

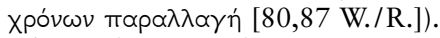

56 Afric., Chronographiae F34 (88-92; 80 W./R.): "But it should be noted that if ever any remarkable story is recorded by the Greeks because of its antiquity, this will be found to have occurred after Moses: the floods and fires, Prometheus, Io, Europe, the Sparti, the rape of Kore, the mysteries, enactment of laws, the exploits of Dionysus, Perseus, the labors of Heracles, the Argonauts, the Centaurs, the Minotaur, the story of Troy, the return of the Heraclidae, the settlement of Ionia, and the Olympics" (English translation by: Adler [see note 3]).

57 See esp. Wallraff, Iulius Africanus (see note 3), XXIII-XXIX, and the fold-out table at the end of the book. I do not agree with what Burgess, Apologetic (see note 8), 35, says on Africanus: "In essence he took Clement's forty-seven sections, twenty-eight pages of the GCS text, and expanded them into five books." It is quite dubious whether he actually knew Clement's treatise. His remark on Clement's floruit under Commodus (Afric., 
of knowledge. Theophilus had called people interested in universal history (including himself) $\phi ı \lambda \circ \mu \alpha \theta \varepsilon \tilde{s}$ and $\phi \iota \lambda \propto \lambda \eta \theta \varepsilon \tilde{\varepsilon}^{58}$, translated freely: real scholars. And we know of him that he also wrote a work $\pi \varepsilon \rho i$ í $\tau$ торі $\tilde{\omega} \nu^{59}$, again translated freely: pure historiography. The apologetic and the scientific approach do not exclude one another; rather we find both strains combined right from the beginning of Christian chronography. But in the long run the aspect of Wissenschaft prevailed. Africanus could therefore be called the father of scientific Christian chronography.

This would require again a discussion of Hippolytus: his commentary to Daniel seems to antedate Africanus, whereas his chronicle is a reaction to it. However, this work as well as the later and more famous work by Eusebius of Caesarea does not belong any longer to the origins of the genre. To sum up, I conclude with three major points.

1. The interest in universal history in Christian authors develops in the second and third century. In this process Christians discover the extraordinary heritage of the Jewish historiographic tradition. Interestingly, this discovery happens after "the parting of the ways", i.e. when Christian communities had already developed an identity distinct from their Jewish roots. However, Christian intellectual writers claimed to be in continuity with the heritage of the past, because it gave them an invaluable advantage in the dialogue with Hellenistic historiography, where the interest in universal history had been growing for some time. Chronology on the basis of the bible helped resolve some long-standing problems, especially in the context of primordial history. The primary goal, in most cases, was to prove the priority (and, hence, superiority) of Moses over Homer. The argument of chronological priority gave the opportunity to depict the relationship between Hebrew and Greek history in a new light. It is certainly not misleading to use the term "apologetic" to describe this approach, both as a literary genre and as a theological way of arguing. However, the polemical tone in the first preserved treatises should not distract from the intellectual challenge of these efforts. Moreover, even if apologetics was one of the roots of Christian universal history, it faded very soon in the development of the genre. While in Tatian and, to a certain extent, Theophilus this can still be perceived clearly, Clement and Africanus only show traces of this approach. The key to the understanding of their works is not so much an attitude of concurrence and therefore polarization between Christian and pagan readings of the past, but rather an interest in dialogue and mutual intellectual enrichment. In this sense Africanus's work can be characterized as scholarly rather than apologetic.

Chronographiae F97 [292 W./R.]) does not say much (contra Burgess, Apologetic [see note 8],33), and there are no clear signs of literary relationships.

58 Thphl. Ant., Autol. III 17,5 (117,10f. M.).

59 Eus., h.e. II $28,30 \mathrm{f}$. 
2. It certainly is true that this dialogue can develop only in an atmosphere where the expectation of an imminent end of time has subsided to a certain extent. Someone who expects the end of the world tomorrow would not waste his time writing verbose chronographies. If the end of time is postponed, it might be tempting to see universal history as a way of calculating the duration of this delay. However, the development of early Christian eschatology and, in particular, of apocalyptic literature seems to be quite independent of the discovery of universal history in Christianity ${ }^{60}$. Themes like the 6000 years and the great Sabbath only occasionally intermingle with chronography. The authors whose works have been analyzed are not normally concerned with millennialism or chiliasm. It has to be admitted, though, that our perception of the material is highly selective. We know of authors interested in universal history like Cassianus, Judas or the "anonymous author of the $10^{\text {th }}$ year of Antoninus" whose works are not preserved ${ }^{61}$. Others may have existed. In some of these cases we can assume that they have not survived because their concrete eschatological expectations were disappointed, and the works therefore lost interest. This was the case with Judas - interestingly his lost chronicle was written at the same time as Hippolytus' commentary on Daniel in a phase of acute persecution.

3. Not much of what has been said is specific to Christians. Almost everything could have been said in similar terms by Jewish authors as well, and probably actually was said by such authors. The person and biography of Jesus and his message did not play a fundamental role. The dating of Moses was more important than Jesus. Only in an advanced stage of the process did reflections on the events in the life of the Savior assume some importance. If universal history ultimately developed more robustly in the context of Christianity, it is not because of Christology, at least not in a direct way. Rather its development should be explained by the fact that the community generally had more open borders, and hence on a social rather than dogmatic basis (on the other hand, it is also true that behind the social reality there are also theological motifs).

Last, but not least, we should always bear in mind that this whole literature was of interest only to a restricted group of intellectuals. The "scientific" approach that grew increasingly important in the course of the process made an elitist enterprise of it.

60 On this topic see now J. Lössl, “Apocalypse? No.” - The Power of Millenialism and its Transformation in Late Antique Christianity, in: A. Cain/N. Lenski (eds.), The Power of Religion in Late Antiquity, Farnham 2009, 31-44. The line from the New Testament and the early Christian apocalypses to Augustine's City of God touches writers like Papias, the author of the Epistle of Barnabas, Irenaeus, Victorinus of Poetovium, Lactantius or Jerome, not the early authors interested in universal history.

61 Cassianus: Clem., strom. I 21,101,2 (see also III 13,91-93) and Eus., h.e. VI 13,7; Judas: Eus., h.e. VI 7; anonymous author: see note 38 . 


\section{ZUSAMMENFASSUNG}

Die Chronographiae des Julius Africanus können als das erste umfangreiche und eigenständige literarische Werk einer Universalgeschichte im Christentum gelten, gleichwohl gab es diverse kleinere Traktate ähnlichen Inhalts, die im zweiten und frühen dritten Jahrhundert abgefasst wurden; sie sind nur teilweise erhalten. Die wichtigsten Texte stammen von Tatian dem Syrer, Theophil von Antiochien und Klemens von Alexandrien.

Oft wird angenommen, dass Geschichtskonzepte im frühen Christentum in enger Beziehung zur Eschatologie stehen, Chronographie und Chiliasmus miteinander verbunden sind. Eine genaue Analyse der Texte zeigt jedoch, dass eine solche Verbindung entweder nicht bewiesen werden kann oder dass sogar - ganz im Gegenteil - einige Autoren kein Interesse an Eschatologie hatten. Obwohl Arithmetik und genaue historische Berechnungen eine grosse Rolle spielen und obwohl der Rahmen der Geschichte in einigen Fällen durchaus als chiliastisch bezeichnet werden kann (in dem Sinn, dass für die Geschichte der Menschheit eine Gesamtdauer von 6000 + 1000 Jahren angenommen wurde), gab es wenig Interesse an einer genauen Berechnung des Endes der Zeit. Außerdem wird die Beziehung zwischen Historiographie und Apologetik diskutiert. Es steht außer Frage, dass die Ursprünge der literarischen Gattung Universalgeschichte in der apologetischen Tradition frühchristlicher Theologie liegen. Im Falle von Tatian und Theophil (bis zum gewissen Grad auch bei Klemens) sind die chronologischen Traktate in größere Werke eingebettet, die einen kritischen Dialog mit zeitgenössischer paganer Philosophie zum Ziel haben. Der Altersbeweis spielt dabei eine zentrale Rolle, im besonderen die chronologische Beziehung zwischen Moses und Homer. Während dieser Gedanke zum Verständnis von Tatian und Theophil weitgehend ausreicht, zeigen spätere Autoren eine Emanzipation der literarischen Gattung Chronographie von den apologetischen Wurzeln. Bis zum gewissen Grad bei Klemens, aber ganz sicher bei Julius Africanus treten diese Wurzeln in den Hintergrund. 